\title{
REFLEXIONS ABOUT THE VALUE OF BREASTFEEDING AS A HEALTH PRACTICE: A NURSING CONTRIBUTION
}

\author{
Valdecyr Herdy Alves ${ }^{1}$, Diego Pereira Rodrigues², Vitória Regina Petters Gregório3o , Maria Bertilla Lutterbach \\ Riker Branco ${ }^{4}$, Rosangela de Mattos Pereira de Souza ${ }^{5}$, Cléria Maria Calheiros da Silva Herdy Alves ${ }^{6}$
}

\footnotetext{
${ }^{1}$ Ph. D. in Nursing. Professor in the Maternal and Child and Psychiatric Department of the Aurora de Afonso Costa School of Nursing (SNAAC). Fluminense Federal University (FFU). Rio de Janeiro, Brazil. Email: herdyalves@yahoo.com.br

${ }^{2}$ Master's student in Health Care Sciences at SNAAC/FFU. Rio de Janeiro, Brazil. Email: diego.pereira.rodrigues@gmail.com

${ }^{3}$ Ph.D in Nursing. Professor in the Nursing Department, Santa Catarina Federal University. Santa Catarina, Brazil. Email: vitoria@ccs.ufsc.br

${ }^{4}$ Master's student in the Maternal and Child and Psychiatric Department at SNAAC/FFU, Rio de Janeiro, Brazil. Email: bertilla@vm.uff.br

${ }^{5}$ Master's student in the Maternal and Child and Psychiatric Department at SNAAC/FFU, Rio de Janeiro, Brazil. Email: rosangelademattos@yahoo.com.br

${ }^{6}$ Master's student in the Maternal and Child and Psychiatric Department at SNAAC/FFU, Rio de Janeiro, Brazil. Email: cleriaherdy@yahoo.com.br
}

\begin{abstract}
The study aims at the identification and analysis, under the view of the nurses, of the axiological value process of the promotion, protection and support related to the maternal breastfeeding. It presents a qualitative and descriptive approach. 11 acting nurses had participated on the Program of Maternal Breastfeeding - Amiga da Amamentação (Breatsfeeding Friend) Basic Unit Initiative in Rio de Janeiro city. In the analysis, the formulation of thematic categories and the articulation with Max Scheler Value Theory were chosen. The data demonstrated the operational form linked to the guidelines of Health Ministry, as nutritional approach, instead of recovering the breastfeeding woman as a familiar and social value of the care net, which threatens the value of breastfeeding and prevents the entire potential of feeling/knowing/doing. We conclude that the comprehension of the value of care related to biological, cultural and social aspects, grants the breastfeeding caring quality and that it has to be more and more valued and stimulated, as breastfeeding deepens the affection link between mother and child.
\end{abstract}

DESCRIPTORS: Nursery. Breast feeding. Social values.

\section{REFLEXÕES SOBRE O VALOR DA AMAMENTAÇÃO COMO PRÁTICA DE SAÚDE: UMA CONTRIBUIÇÃO DA ENFERMAGEM}

RESUMO: O estudo objetiva identificar e analisar, sob a ótica de enfermeiros, o processo de valoração axiológica da promoção, proteção e apoio ao aleitamento materno. Apresenta uma abordagem qualitativa, descritiva. Participaram 11 enfermeiras atuantes no Programa de Aleitamento Materno - Iniciativa Unidade Básica Amiga da Amamentação, no Município do Rio de Janeiro. Na análise optou-se pela formulação de categorias temáticas e a articulação com a Teoria dos Valores de Max Scheler. Os dados evidenciaram a forma operacional vinculada aos cumprimentos do Ministério da Saúde, como enfoque nutricional, ao invés de regatar a nutriz como valor social, familiar da rede de cuidado, que compromete o valor da amamentação e impede o pleno potencial do sentir/saber/ fazer. Conclui-se que a compreensão do valor do cuidar, nos aspectos biológicos, culturais e sociais, garante a qualidade assistencial da amamentação, e deve ser cada vez mais valorizada e incentivada, pois a amamentação aprofunda o vínculo afetivo mãe/filho.

DESCRITORES: Enfermagem. Aleitamento materno. Valores sociais.

\section{REFLEXIONES SOBRE EL VALOR DEL AMAMANTAMIENTO COMO PRÁCTICA DE SALUD: UNA CONTRIBUCIÓN DE LA ENFERMERÍA}

\begin{abstract}
RESUMEN: El estudio objetiva identificar y analizar, bajo la óptica de enfermeros, el proceso de valoración axiológica de la promoción, protección y apoyo al amamantamiento materno. Presenta un abordaje cualitativo y descriptivo. Participaron 11 enfermeros actuantes en el Programa de Amamantamiento Materno - Iniciativa Unidad Básica Amiga da Amamentação (Amiga del Amamantamiento) en el Municipio de Rio de Janeiro. Para el análisis, fue utilizada la formulación de categorías temáticas y la articulación con la Teoría de los Valores de Max Scheler. Los datos evidenciaron la forma operacional vinculada a las directrices del Ministerio de Salud, como enfoque nutricional, en vez de rescatar a la nodriza como valor social y familiar de la red de cuidado, lo que compromete el valor del amamantamiento e impide el pleno potencial del sentir/saber/hacer. Se concluye que la comprensión del valor del cuidar en los aspectos biológicos, culturales y sociales garantiza la calidad asistencial del amamantamiento y debe ser cada vez más valorizada e incentivada, pues el amamantamiento profundiza el vínculo afectivo madre/hijo.
\end{abstract}

DESCRIPTORES: Enfermería. Lactancia materna. Valores sociales.

Text Context Nursing, Florianópolis, 2014 Jan-Mar; 23(1): 203-10. 


\section{INTRODUCTION}

Breastfeeding takes on different meanings, according to various cultures, thus, breastfeeding becomes a habit associated with social determinants and cultural manifestations, influenced by the same conceptions and values indicated in the process of socialization of the woman. ${ }^{1}$ So we ask: What is breastfeeding? What is the meaning of maternal breastfeeding?

To breastfeed means to nurse, suckle, lactate, feed, nourish. Already, lactation is synonymous with breastfeeding, from the point of view of its definition, coated in the same functional connotation of breastfeeding or raising the child with the milk that is produced. Therefore, the meaning of both words is not restricted to the purely biological sphere of action, but rather exceeds it by translating the emotions surrounding the woman's relationship with her child, family and the world around her. ${ }^{2}$

The Ministry of Health survey, conducted in all Brazilian capitals and in the Federal District, summing information about 34,366 children, concluded that the mean duration of breastfeeding in the country increased in the capitals and the Federal District, from 296 days in 1999, to 342 days, in 2008. In the same period, the median duration of exclusive breastfeeding reached 51.1 days (1.8 months), while breastfeeding supplemented by other foods was 341.6 days (11.2 months), in the group of Brazilian capitals and the Federal District. $^{3}$

This increase was due, in large part, to the National Program to Encourage Breastfeeding, created in 1981 by the Ministry of Health, combining multisectoral actions, particularly in the areas of social communication, health care and legislation. ${ }^{4}$ However, the rates achieved are still quite distant from the recommendations of the United Nations Fund for Infancy (UNICEF) and the World Health Organization (WHO), which proposed exclusive breastfeeding for six months and supplemented breastfeeding by family foods, until two years of age, or more. ${ }^{5}$

Accordingly, in order to stimulate and equip the basic health network to deploy a set of procedures to promote, protect and support breastfeeding in prenatal services and in the hosting/triage of mother and newborn (NB) in the primary health system, the Municipal Secretariat of Health and Civil Defense of Rio de Janeiro (MSHCD / RJ) in 1999, in a pioneering way, implemented the Breast- feeding Friendly Primary Care Initiative (BFPCI) in 11 health units. This role, a result of demand of an Inter-Institutional Technical Group to Encourage Breastfeeding, beginning in the second half of the 90 s, is to train primary care teams working with pre-natal, child and postpartum care followup activities, in the management and support of breastfeeding, constituting a valuable opportunity for health services in promotion, prevention and solution of problems that may contribute to early weaning. ${ }^{6}$

The child health policies in Brazil have recommended, among other actions, the promotion, protection and support of breastfeeding. ${ }^{7}$ So, the process of breastfeeding assessment must be understood, which allows the understanding that humans have three fundamental forces: thought, feeling and will. Thus, we must distinguish between the rational, emotional and volitional intuition, which, in turn, has three aspects: essence, existence and value. In this sense, emotional feeling has an immediate reference to the object, and through this it knows the figures relating to human existence or their mental or psychophysical organization. Herein lies the foundation of scheleriana axiology, aimed toward the values whose a priori principle is considered as material values, objects made of a non-formal essence, in other words, the existence precedes the existence of being. ${ }^{8}$ Given the above, and for contemplation in the present study of the multiple aspects involved in the practice of breastfeeding care, the following goal was established: to identify and analyze, from the nurse's perspective, the process of axiological valuation of promoting, protecting and supporting breastfeeding.

\section{METHOD}

This was a descriptive study with a qualitative approach, aimed at the enhancement of subjective data in social research, which is an integral part of qualitative methods, obtaining descriptive data, through direct and interactive contact with the researcher's study situation. ${ }^{9}$ The investigation was conducted after the examination and approval of the Municipality Research Ethics Committee from Rio de Janeiro City, approved as required by Res. 196/96 of the National Health Council, under Protocol CAAAE 0061.0.313.313-09.

The study population consisted of 11 nurses working in the Breastfeeding Program, with the title of Friend of the Breastfeeding being the inclusion criteria. All the nurses signed the Terms of Free and Informed Consent, conditioning their 
participation, ensuring anonymity and confidentiality of information, confirmed with the use of an alphanumeric code (E1... E11). The exclusion criteria took into account the inexperience regarding routines of the section.

For data collection, individual interview was conducted through the use of a semi-structured instrument, with open - and closed-ended questions. The data collection occurred during the months of January to March 2010, in the respective workplace units of the research subjects. The interviews were tape recorded with the permission of the respondents and later, the transcript of the testimonies occurred, which were validated by the interviewees, prior to conducting the analysis.

To analyze the data collected, the formulation of thematic categories was chosen, ${ }^{9}$ and in the final step of the analysis, links were established between the data collected and the Values Theory of Max Scheler; a philosophy of values, that in addition to being developed in opposition of the axiological rationality, could be considered in terms of an expansion of the knowledge domain that, until then, favors the intellectual logical processes revealed through emotional intuition, that is, through emotional feeling. ${ }^{8}$ This enabled discussion and establishment of the point of view to reach the proposed study aim.

\section{RESULTS AND DISCUSSION}

The study participants were female $(11=$ $100 \%)$, predominantly aged between 35 and 45 years (8), configuring a population possibly more interested and with more time for intellectual improvement, particularly in relation to issues related to breastfeeding. Regarding the completion year of the undergraduate course, it was found that ten of the interviewees had graduated more than ten years ago, enabling changes arising from the dizzying technical and scientific development, resulting in the improving of their technical and humanistic skills in their professional practice performance.

To investigate the training completed within the past five, in the theme of breastfeeding, it became apparent that the 11 nurses had attended the training course associated with breastfeeding, thus, bringing a positive outlook for care, based on scientific knowledge that should guide the work of nursing. In this case, the quality of women's, infant and family health care in the issues of clinical management breastfeeding. Regarding the operat- ing time of the study participants in the areas of breastfeeding, the higher frequency was between 11 and 15 years, totaling eight of the interviewees, helping to understand the everyday evaluative construction of nursing care dispensed to nursing mothers, a process that met the values and countervalues that involved the act of breastfeeding.

\section{Promoting, protecting and supporting breastfeeding as a social value}

The multiple and conflicting positions about the nature of value - chains that comprise the Values Theory, and the scarcity of studies focusing on the influence of values in nursing ideals, led to the need to seek authors, aiming to assist the researcher in the interpretation of the content of the obtained evidence.

It was considered that the fundamental support of discourse analysis was the language that expressed the dominant ideology in oral language, understood here as the speech of the interviewees. Therefore, the analysis of the nurses' discourse involved thinking about the need to maintain the notion of language as an indispensable prerequisite for thinking of the discursive processes. ${ }^{10}$

In this line of reasoning, the rereading of the content of the interviews showed, once again, the dichotomy between the thinking and acting of each nurse, linked to their operational form of care, often routinely performed in compliance with the procedures established in the Ministry of Health guidelines, apparently uncompromising with the reality of every woman. In fact, this form of care should have been based on reflective critical thought, through which greater safety to the nursing mothers could have been better conveyed, related to the clarifications regarding breastfeeding, also emphasizing the values that encase this act, not only as recommended in the official rules, but mainly according to their own value-based point of view. ${ }^{6}$

Not doing so, nurses gave rise to a discourse that ultimately did not satisfy the parties involved in the breastfeeding process: themselves, who should clarify, and the breastfeeding mother, who sought their support and help for the success of this process. In this sense, one interviewee made a reflection with respect to this, stating:

[...] breastfeeding is a network in which everyone should be involved, all professionals: nurses, nursing technicians, nutritionists, physicians [...] it is our duty to promote, protect and support the woman, her baby 
and her family. It is difficult, but it is their right and citizenship [...] (E2).

But, what occurs, in reality, is the routinization of the official discourse proclaimed daily, whose focus is restricted to the nutritional and immunological value of breast milk, without properly valuing the affective and emotional aspects of the issue, that involve both the woman and the child.

Scholars of the theme ${ }^{11}$ confirmed that the majority of the official programs developed educational activities for nursing mothers, focusing on technical and biological aspects of breastfeeding. Therefore, it is important that the nurse seeks to identify the perceptions of the woman about breastfeeding, which does not always occur, because according to one interviewee:

[...] the women do not give much importance to breastfeeding (E6).

Although the aspects related to guidance about breastfeeding techniques and other informative elements, from the biological point of view, has an important role, only the concrete reality of being a mother will give to the woman elements to define actions and to make decisions about breastfeeding, since the practice of breastfeeding is an experience that implies the involvement of a series of maternal factors and others related to the newborn, which is not exclusively reliant on a prior decision to breastfeed or not. ${ }^{12}$ These factors were highlighted by two interviewees, with an emphasis on the bond between mother and child:

[...] I say that is just has a lot of affection and love in the family that everything is more tranquil. The bond is constructed in the family [...] (E3).

[...] I believe that, for successful breastfeeding, the woman has to make a bond, indeed, has to make bond during the prenatal period, delivery, and life with her family, or everything become more complicated; a child is for all of life [...] (E4).

Referring to the nutritional value of human milk, one interviewee said that it has all the advantages, all, but that [...] they [the mothers] do not understand that is an appropriate diet, that it does not have $a$ cost and is safe for the baby [...] (E6), while others interviewed confirmed the benefits of maternal breastfeeding:

breast milk is safe, is ready, the woman does not have to do anything, just get the breast and give. Want something better? And it is also a vaccine [...] (E2).

the baby has all the advantages in breast milk when the mother delivers on free demand. This favors the baby that he gets all the nutrients needed to stay strong and handsome, with immunity against some diseases [...] (E10).

Incidentally, the scientific literature ${ }^{13}$ that focuses on the benefits of breastfeeding, repeatedly confirms the value of breast milk and the advantages it presents for the baby, corroborating the opinion of the nurses above. To illustrate, here are some of these advantages: it contains enough water, more appropriate protein and fats for the child, plus vitamins in sufficient quantities, eliminating the need to use vitamin supplements, and protects against allergies and infections, especially diarrhea.

Breastfeeding is love, bonding, adequate nutrition [...]. We, nurses, are always working on it, it is a routine to talk about this [...] (E3).

On the other hand, the clipping of the interview with interviewee E6, featured above, hint at the possibility of overcoming the dichotomy mentioned above, in search of subjective/objective dimensions contained in the discourses of the interviewees, which revealed not only the value of the phenomenon, but also their relationship with breastfeeding, where the actual self-protective speech, as one who, while reflecting what everyone knows, might stop, allowing silence that each understands without confessing. ${ }^{6,10-11}$ This could be the issue embedded in the nurses' discourses who, when not really involved with the value of breastfeeding, let pass the opportunity to make a clarification in its fullest, in order to mechanically reproduce only what is established.

In their statements, two interviewees did mention the major changes that occur in the life of the woman whose baby has just been born:

[...] pregnancy, labor and birth favor growth for the woman and for her family, life changes, the meaning of everything [...] (E1).

[...] you need to stimulate the mother, she needs protection and support [...] they made the guidelines. Some are interested, some not [...] what can I do? (E11).

It is valid to record that the first days after birth are crucial to breastfeeding because it is during this period that lactation is established, as well as being a period of intense learning for the mother and adaptation for the newborn. It is understood that it is necessary that health professionals work with the postpartum woman and her family, seeking to solve any problems or dificulties. ${ }^{14}$ Therefore, some interviewees emphasized the evaluative discourse in favor of breastfeeding: 
breastfeeding is a unique moment in the life of the woman and her family [...] this experience is only for her, $[. .$.$] we support, but the lived experience is hers$ [...] (E1).

[...] to seek out this woman for the breastfeeding experience, $[. .$.$] the issue of the values of the own woman$ / mother [...] (E6)

[...] It is a great treasure, breastfeeding, [...] value for the life of the woman [...]. Therefore, we must discuss, must talk [...]. Breastfeeding has many benefits for the woman (E7).

What has been said confirms the fact that, since the clinical nurses' beings are historically constituted, their discourses tend to be incomplete in that they are produced at the moment lived, conforming to the surrounding reality, leading them to the annulment of their own voices when confronting what has been established by the academic world, by governmental public health policies, by the fads, with regard to breastfeeding and, even, by certain disinterest in deepening, together with the nursing mothers, a topic of multifaceted human and social complexity. In this sense, when one reads, not only what is said is considered, but also what is implied: what is not said and that meaning is also essential for a discourse that breaks with the plenitude of thinking of the nurse on the issue of the practical experience of care. ${ }^{15}$

This behavior compromises their statements about the value of breastfeeding, harming their relationship with the externality and preventing the development of their full professional potential, to the feeling of pressure from the constant demands on what to do and how to do it, the results obtained and so many other issues, not adequately met, lead to discouragement that leads to the incompleteness of the act of clarifying, making the voice of the nurse increasingly fragmented with the lactating women.

The social value is found deeply rooted in what is the most intimate of human beings; it is immanent to it, it is the essence of his existence and has, therefore, the highest significance for understanding the process of clarification of breastfeeding transmitted to nursing mothers, by the nurse, in her professional practice. ${ }^{6}$ This is also the understanding of the interviewee, E2, transcribed below:

[...] breastfeeding is a network where everyone should be involved, all professionals: nurses, nursing technicians, nutritionists, doctors [...]. It is our duty to promote, protect and support the woman, her baby and her family, it is difficult, but it is their right and citizenship [...] (E2).

It is noticed that, in relating breastfeeding and citizenship, this discourse shows itself committed to real social problems experienced by the lactating mother, understanding that the valuation of the latter is an issue of conquest, and not of giving, and that breastfeeding, in its broadest sense, is interrelated with this valuative achievement. Another participant complements this, affirming that:

[...] the lack of family involvement. They should also provide support, because women return to work, yes, but who can take the cup with milk extracted from the mother? This we will have to talk about, it is important, we must guide [...] (E5).

Thus, when transmitting clarification about breastfeeding, working with promotion, protection and support, in their discourses, nurses seek to rescue the social value of the family and of the woman as a member of a network of care, even using a language compromised with issues inherent in a contradictory society in what is said with respect to breastfeeding. ${ }^{6}$

Breastfeeding suffers constant evaluations on the part of the woman, influenced by her context, her life goals and the personal vision of the experience, which are determinants of the meanings of this experience for the baby and for her, portrayed in terms of risk and benefits. ${ }^{16}$ These evaluations influence the decision of the nursing mother to breastfeed or not, depending on the priority demands for the child or for herself. For one of the interviewees, nursing needs to rescue the social value of the woman, namely, needs to value the breastfeeding woman because, from her perspective:

[...] is not easy, there are several issues: work, other children, family, [...] we only determine what she has to do, but do not look to her issues [...] (E4).

The difficulties that the mothers must overcome to continue breastfeeding their child are many, and one of them - perhaps the most common - is spelled out in the statement below:

[...] we give guidance, the laws are here, but do not apply. For example, labor laws: the maids are unprotected, that's a fact. They cannot take their babies [to the workplace], then how are they to only breastfeed for six months? [...] (E3).

In this particular case, it is important to remember, as already mentioned, that in March 2008, the Brazilian government enacted Law n. 11,770, extending maternity leave by 60 days, taking it 
from 120 to 180 days, thus ensuring the possibility for nursing mothers to continue breastfeeding their children. ${ }^{17}$

The return to paid work outside the home is another constant concern of the woman who decides to breastfeed her child, because she needs help to reconcile her various tasks, in particular, in the case of first-time mothers, her family's support is essential.

Two interviewees opined in this regard, emphasizing in their statements a real concern about this problem, which, according to both of them, deserves to be widely discussed so that they can reach a solution that satisfies everyone for the child's benefit:

the lack of family involvement. They should also provide support, because women return to work, yes, but who can take the cup with milk extracted from the mother? This we will have to talk about, it is important, we must guide (E5).

we have to make rounds of debate, create informative debate, call the community, promote groups for strengthening the breastfeeding and the women who breastfeed. We have to talk to the commerce people, businesses, all of these [...] (E8).

These discourses focus on promotion, protection and support of breastfeeding, together with the nursing mothers who experience social needs in the field of breastfeeding, the reason why they need to be looked after in their demands, so that they can overcome the difficulties that arise in their life trajectories. The social values of the woman who breastfeeds are clearly contained in these discourses, highlighting the comprehensiveness as social action resulting from the ongoing interaction of the actors demand and supply in the relationship together with the women and their families.

It is emphasized that the faculty of exchange evaluative experiences determines the extinction of the art of narrating, since the narration is not only the product of the voice, but all that is learned in the social life. ${ }^{6}$ Thus, she asks herself: how to uncover for the breastfeeding mothers the social value of breastfeeding in the network of promotion, protection and support?

It is known that every problem is always imposed by the historical, social and economic problem, whose forces escape the difficulties of groups, institutions and individuals. ${ }^{6}$ This does not mean that the institutions, groups and individuals are not participating in the context and its constitution. On the contrary, it means that the social historical context of an era exerts impositions and pressure through the institutions, groups and individuals.

At the present time, the impositions and pressure are becoming ever more present in the life of the woman, forcing her to adopt postures and to make decisions regarding the problems that arise in their daily lives. One of these problems is related to the children, from the possibility of having them, to how to feed and raise them.

The issues of promotion, protection and support of breastfeeding cannot be discussed in isolation, they should be integrated at individual, family, institutional and national levels. Thus, in order to legitimize this worldview about breastfeeding, the nurse needs to spread her ideas, values and beliefs so that, experiencing society, she can justify the established order, because it is through the promotion, protection and support of breastfeeding she finds one form of reproduction of social relationships and their conception of the world in relationship to the social values of breastfeeding, as reported in the following part of the statement:

day by day women have no support, no labor protection, they live dodging all difficulties. It is very difficult, they do not know their rights, lack of knowledge, the lack citizenship. Our role is this, of guiding (E1).

When this nurse makes reference to the lack of support and labor protection, in a society such as ours, in which the capitalist system of production prevails, in which profit is the desire that drives all the achievements, sometimes at any cost, it has been the valuation of the productivity for high scale. In this society, language is used in a perverse way, because it inhibits the deepest being of man as well as submits, culminating with the need to define the dominant class, namely, one able to reproduce the conditions deemed essential to the perception of his domain. In her discourse, which gives us a glimpse that her professional practice is permeated by social values, acquired during academic formation or resulting from her personal relationships, having one of the values directly interwoven in the family structure and in the approximation of its members, leading this nurse to reflect upon the position of the breastfeeding mother in contemporary society.

Thus, this valuative discourse should also include insights into the labor legislation protecting motherhood, of which the majority of nursing mothers were unaware of the content, always remembering the social value attributed to breast milk. Given the above, the nurse, while embodied 
consciousness, can reveal or unveil for mothers the social values of breastfeeding, may boost valorative possibilities of breastfeeding, based on promotion, protection and scientifically recommended support and, especially, her own unique look about the subject, seeking to transcend what is already implicit in the act of breastfeeding, then reaffirming their personal and professional values, revealing the way of seeing herself, others and life, as possibilities to make the experience happen, by the mothers, the phenomenon of breastfeeding in all its fullness.

\section{CONCLUSION}

The reflections about the topic in focus, approaching the studies of Max Scheller, permit the perception of the need to uncover the thinking of nurses who work with pregnant and postpartum women, and for the breastfeeding mothers with regard to the valuation of the act of breastfeeding. It is through the valuation - this way to value - that they ensure their professional presence in the line of care for the breastfeeding mother, they emerge and institute their personal values as brands in the healthcare process, guided in the biological, cultural and social aspects of the phenomenon of breastfeeding.

Constructed with an axiological basis and the contributions of valuative discourse of nurses, understanding the language as the primary mediator between them and the lactating women, the study aimed to understand the role of the nurse in her practice of taking care of those who have and those who intend to breastfeed, or not to do so, since new pathways need to be explored, taking into account the care in the valuative perspective of promotion, protection and support of breastfeeding.

It was possible to observe that the discourses are impregnated by what is advocated in the protocols and health programs that claim the promotion, protection and support of breastfeeding, valuing the process of care of the health of women, of the baby and the family, although some values expressed are also supported in the natural, biological sciences, it is approaching the social, from the human.

This enables us to understand that there are concerns about breastfeeding as a value in itself; with regard to the bond between mother and baby, its value is considered as a pathway to breastfeeding success and ensuring food security necessary for the baby. By means of this valuative occurrence, nurses revealed their power to be impregnated with humanistic and social values that reaffirmed the concern that they had with the care that should be dispensed to women during the breastfeeding phase.

\section{REFERENCES}

1. CruzSH, Germano JA, Tomasi E, Facchini LA, Piccini RX, Thume E. Orientações sobre amamentação: a vantagem do programa de saúde da família em municípios gaúchos com mais de 100.000 habitantes no âmbito do PROESF. Rev Bras Epidemiol. 2010 Jun; 13(2):259-67.

2. Souza KV, Tesin RR, Alves VH. Mães de recémnascidos hospitalizados: em/entre círculos no processo de amamentação. Acta Paul Enferm. 2010 Out; 23(5):608-13.

3. Ministério da Saúde (BR). Secretária de Atenção à Saúde. II Pesquisa de prevalência de aleitamento materno nas capitais brasileiras e distrito federal. Brasília (DF): MS; 2009.

4. Issler H. Aleitamento materno no contexto atual políticas, práticas e bases científicas. São Paulo (SP): Sarvier; 2008.

5. Machado MMT, Bosi MLM. Compreendendo a prática do aleitamento exclusivo: um estudo junto a lactantes usuárias da rede de serviços em Fortaleza, Ceará, Brasil. Rev Bras Saude Mater Infant. 2008 Mar; 8(2):187-96.

6. Alves VH. Reflexões sobre o valor da amamentação como prática de saúde: uma contribuição da enfermagem [tese]. Rio de Janeiro (RJ): Universidade Federal Fluminense. Departamento Materno-Infantil e Psiquiátrico; 2010.

7. Teixeira MA, Nitschke RG. Modelo de cuidar em enfermagem junto às mulheres-avós e sua família no cotidiano do processo de amamentação. Texto Contexto Enferm. 2008 Jan-Mar; 17(1):183-91.

8. Scheler M. Da reviravolta dos valores. $2^{\mathrm{a}}$ ed. Petrópolis (RJ): Vozes; 2012.

9. Minayo MCS. O desafio do conhecimento: pesquisa qualitativa em saúde. $12^{\circ}$ ed. São Paulo (SP): Hucitec; 2010.

10. Orlandi EP. As formas do silêncio: no movimento dos sentidos. $6^{\text {a }}$ ed. São Paulo (SP): UNICAMP; 2007.

11. Costa VC. Práticas educativas pró-amamentação em uma maternidade credenciada pela Iniciativa Hospital Amigo da Criança [Dissertação]. Pernambuco (PE): Universidade Federal de Pernambuco; 2012.

12. Oliveira MIC, Souza IEO, Santos EM, Camacho LAB. Avaliação do apoio recebido para amamentar: significados de mulheres usuárias de unidades básicas de saúde do Estado do Rio de Janeiro. Ciênc. Saúde Coletiva. 2010 Mar; 15(2):599-608. 
13. Spyrides MHC, Struchiner CJ, Barbosa MTS, Kac G. Efeito da duração da amamentação predominante no crescimento infantil: um estudo prospectivo com modelos não lineares de efeitos mistos. J Pediatr (Rio J). 2008 Jun; 84(3):237-43.

14. Duarte AML, Costa AFF, Oliveira CT, Carvalho LSF. Aleitamento materno: uma abordagem sobre o papel do enfermeiro no preparo de mães adolescentes. Rev Inst Ciênc Saúde. 2008; 26(2):177-82.

15. Orlandi EP. Discurso e leitura. $8^{\mathrm{a}}$ ed. São Paulo (SP): Cortez; 2008.
16. Siqueira FPC. O significado da amamentação na construção da relação mãe e filho: um estudo interacionista simbólico [Tese]. São Paulo (SP): Universidade de São Paulo; 2012.

17. Brasil. Lei n. 11.770, de 9 de setembro de 2008. Dispõe sobre a criação do Programa Empresa Cidadã, destinado à prorrogação da licença-maternidade mediante concessão de incentivo fiscal. Diário Oficial da Republica Federativa do Brasil. 10 Set 2008. Seção 1. 